\title{
Effect of Addition of Coffee Extract on Microbial Growth and Functional Properties of Yoghurt
}

\author{
Jonah Mbae, Richard Koskei, and Beatrice Mugendi
}

\section{ABSTRACT}

Submitted : January 11, 2022

Published : February 13, 2022

ISSN: $2684-1827$

DOI: 10.24018 /ejfood.2022.4.1.445

\section{Jonah Mbae*}

Institute of Food Bioresources Technology, Dedan Kimathi University of Technology, Kenya.

(e-mail; jonahmbae@ gmail.com)

Richard Koskei

Institute of Food Bioresources

Technology, Dedan Kimathi University of Technology, Kenya.

(e-mail; kipkorir.koskei@dkut.ac.ke)

Beatrice Mugendi

Murang'a University of Technology, Kenya.

(e-mail: bmugendi@mut.ac.ke)

*Corresponding Author

\section{INTRODUCTION}

\section{A. Background Information}

Yoghurt is one of the most popular fermented dairy products worldwide which has great consumer acceptability due to its health benefits [1]. In general, yoghurt is considered as a nutrient-dense food and a rich source of bio-available calcium. Yoghurt provides milk proteins with a higher biological value containing the essential amino acids necessary to maintain good health [2]. Yoghurt is considered a probiotic carrier food that delivers significant amounts of probiotic bacteria into the body. Recently, coffee flavoured yoghurt has been developed with the focus of enriching it with functional properties found in coffee and also boost coffee consumption in Kenya. For many years coffee in Kenya has been produced for export and when the international prices fluctuate the effect trickles down to the farmer in terms of loses. This problem has affected coffee production leading to the loss of livelihoods for many families that depend on coffee. Unlike in other coffee growing countries, consumption of coffee is low in Kenya accounting for less than $7 \%$ of the total coffee production [3]. Therefore, as a way to mitigate this loss there is a need promote local coffee consumption. One of the ways is through development of coffee flavored yoghurt. Yoghurt is a product that is fast moving in Kenya and enriching it with coffee would enhance coffee consumption. Coffee beverage is a rich source of bioactive compounds especially polyphenols, such as phenolic acids, mostly chlorogenic (in green beans) and Cafeic (occurring after roasting). The compounds contribute to the total polyphenol intake in diet and are beneficial to consumer health [4]. Most of these compounds have received considerable attention as potentially protective factors against human chronic degenerative diseases (cataracts, macular degeneration, neurodegenerative diseases, and diabetes mellitus), cancer and cardiovascular disease [5], [6]. Coffee flavoured yoghurt offers to the consumer the natural attractive flavour of coffee as an alternative to the use of artificial flavours and colourings that have raised many health concerns around the world due to their difficulties in their break down in the body [7]. The use of these artificial colourings is meant to cut down on cost of production as well as restore the original colour of the food after processing [8]. Coffee extract therefore impacts a natural brown colour into the yoghurt eliminating the need for artificial colours. Consumers of coffee flavoured yoghurt have a potential to enjoy improved nutrition from bioavailability of calcium, provision of live beneficial lactic acid bacteria and also the functional benefits of antioxidants from the coffee extract [9]. The coffee flavoured yoghurt has a better keeping quality due to suppressed growth of yeast and 
moulds. This will also help in promoting food safety due to antifungal effect of the coffee extract [8]. This research aimed at determining the effects of incorporating coffee extract on the viability of lactic acid bacteria and fungi and, the functional properties of the coffee flavoured yoghurt.

\section{MATERIALS AND METHODS}

\section{A. Collection of Samples and Preparation}

All materials were obtained from renowned suppliers. Raw milk was obtained from DeKUT farm, yoghurt culture was bought from Promaco Limited. Sugar, skimmed milk powder obtained from a supermarket in Nyeri town while the coffee extract was prepared from DeKUT coffee research laboratory. Yoghurt was processed by pre-warming twelve liters of milk to $60{ }^{\circ} \mathrm{C}$, then sugar and skimmed milk powder added, and the mixture was clarified using a muslin cloth. The temperature was raised to $90{ }^{\circ} \mathrm{C}$ and held for $30 \mathrm{~min}$ to achieve complete pasteurization. The mixture was then cooled immediately to $45^{\circ} \mathrm{C}$ and the yoghurt bacterial culture was inoculated at the rate of $2 \% \mathrm{v} / \mathrm{v}$. Incubation was done for 6 hours to achieve a $\mathrm{pH}$ of 4.6. The yoghurt was then transferred into the refrigerator overnight for 12 hours.

\section{B. Experimental Design and Treatment}

A Complete Randomized Design (CRD) was used to prepare the treatments of this research. Four treatments in triplicates were prepared by adding coffee extracts to the yoghurt as follows; $0.0 \%$ was the control, $0.1 \%$ coffee extract, $0.2 \%$ coffee extract and $0.3 \%$ coffee extract. This yielded a total of twelve samples packaged into small packages for ease of sampling and analysis. Sampling was done every week for five weeks and were frozen at $-18^{\circ} \mathrm{C}$. Data was analyzed by use of ANOVA and means separated by LSD at $p<0.05$ level of significance.

\section{Microbial Analysis}

Samples were analyzed for microbial counts (lactic acid bacteria and yeast and moulds). Survival of lactic acid bacteria was analyzed using MRS agar medium by the pour plate method and incubated at $30{ }^{\circ} \mathrm{C}$ for 48 hours [8]. The colonies were determined and presented as colony forming unit per $\mathrm{ml}$.

Yeast and moulds were analyzed using potato dextrose agar (PDA) medium by spread plate. One milliliter of the initial dilution was spread on the dried PDA using a sterile stainless steel spreader. Incubated at room temperature for 35 days after which observations were made and presented as $\mathrm{CFU} / \mathrm{ml}[8]$.

\section{Functional Analysis}

Total polyphenolic compounds were determined using Folin ciocateau method as described by Haile and Kang, [8] with some modification. Five milliliters of the sample were pipetted into a test tube and mixed with $5 \mathrm{ml}$ of $0.2 \mathrm{~N}$ Folin Ciocateau reagent, vortexed gently for $5 \mathrm{~min}, 4 \mathrm{ml}$ of $7 \%$ $\mathrm{Na}_{2} \mathrm{CO}_{3}$ added and incubated for 90 minutes. The resultant colour was read using MRC-V16 UV spectrophotometer at $765 \mathrm{~nm}$ wavelength. Gallic acid standard curve was used to interpret the results. Total polyphenolic compounds were presented as $\mathrm{mgGAE} / \mathrm{ml}$ of the sample.

Antioxidant activity was determined using radical scavenging activity using 2,2-diphenylpicrylhydrazyl (DPPH) method as described by Daniel and Workneh, [9], Bobková et al. [10] with slight modifications. Two milliliters of $0.006 \%$ in methanol DPPH solution was mixed with $1 \mathrm{~mL}$ of different concentrations of yoghurt samples and stirred vigorously for $30 \mathrm{sec}$. Then the solutions were allowed to stand in a dark place at $25{ }^{\circ} \mathrm{C}$ for 30 minutes allowing chemical reactions to take place. After $30 \mathrm{~min}$, absorbance was measured against a blank at $520 \mathrm{~nm}$ using MRC V-16 UV-Visible spectrophotometer. Ascorbic acid was used as a standard, and a solution without any sample, but with DPPH and ethanol was used as a control. The results were interpreted using a standard curve and results given as $\%$ DPPH.

\section{RESULTS AND DISCUSSIONS}

\section{A. Effects of Coffee Extract on Lactic Acid Bacteria}

In this research total counts of Lactic Acid Bacteria (LABs) were determined in the coffee flavoured and control yoghurt samples. The results are shown in Table I. In week 1 to 3, treatment $0.3 \%$ showed the lowest significant counts than the other treatments. This could have been contributed by the higher coffee extract concentration that might have increased the acidity of the yoghurt in addition to the generated lactic acid that could have lowered the rapid growth of the LABs. This agrees with previous observations that the growth of LABs during storage is highly affected by low $\mathrm{pH}$ mainly below 4.7 [11]. A different trend was observed in week 4 and 5. The samples with higher coffee extracts concentration showing higher counts of LABs than those with lower coffee concentration. As storage of samples time increased, the effect of coffee extract in lowering the growth of LABs decreased. This could be attributed to the ability of lactic acid bacteria to utilize polyphenolic compounds thus stimulating their growth and lowering any antimicrobial effect thus improving the survival of the LABs as reported earlier that polyphenolic compounds have a positive influence on the growth and survival of lactic acid bacteria [12]. This is in line with the findings of this research. The lactic acid bacteria in all treatments were maintained above $10^{6} \mathrm{cfu} / \mathrm{ml}$, thus the product could be termed as probiotic [12]. Coffee flavoured yoghurt could be stored under refrigeration for more than four weeks and maintain its probiotic quality, as shown in Table I

TABLE I: LACTIC ACID BACTERIA COUNTS IN COFFEE FLAVOURED YOGHURT

\begin{tabular}{cccccc}
\hline \multirow{2}{*}{$\begin{array}{c}\text { Treatments } \\
\text { (\% coffee extract })\end{array}$} & Week 1 & Week 2 & Week 3 & Week 4 & Week 5 \\
\cline { 2 - 6 } Control & $10.1 \pm 0.01^{\mathrm{a}}$ & $10.0 \pm 0.1^{\mathrm{b}}$ & $9.30 \pm 0.02^{\mathrm{a}}$ & $5.23 \pm 0.02^{\mathrm{d}}$ & $4.96 \pm 0.02^{\mathrm{a}}$ \\
0.1 & $10.8 \pm 0.02^{\mathrm{a}}$ & $10.4 \pm 0.02^{\mathrm{a}}$ & $7.76 \pm 0.01^{\mathrm{c}}$ & $6.93 \pm 0.02^{\mathrm{c}}$ & $3.70 \pm 0.02^{\mathrm{c}}$ \\
0.2 & $10.9 \pm 0.03^{\mathrm{a}}$ & $10.6 \pm 0.03^{\mathrm{a}}$ & $8.56 \pm 0.02^{\mathrm{b}}$ & $8 \pm 0.02^{\mathrm{b}}$ & $4.23 \pm 0.0^{\mathrm{b}}$ \\
0.3 & $9.13 \pm 0.02^{\mathrm{b}}$ & $9.4 \pm 0.02^{\mathrm{c}}$ & $7.36 \pm 0.02^{\mathrm{d}}$ & $8.40 \pm 0.02^{\mathrm{a}}$ & $5.40 \pm 0.03^{\mathrm{a}}$ \\
\hline
\end{tabular}

The values are mean \pm standard deviation (SD) of three replicates. Values within a column marked with different superscript letters are significantly different $(\mathrm{P}<0.05$ ) 


\section{B. Yeast and Moulds Counts in Different Treatments of Yoghurt}

Yeast and moulds in coffee flavoured and non-coffee flavoured yoghurt was studied for five weeks during cold storage. The results as shown in Table II indicated that concentration in the control $(0.0 \%)$ ranged from $11.3 \times 10^{0}$ to $36 \times 10^{0} \mathrm{cfu} / \mathrm{ml}$, treatment $0.1 \%$ ranged from $9.87 \times 10^{0}$ to $8.33 \times 10^{0} \mathrm{cfu} / \mathrm{ml}$, treatment $0.2 \%$ gave a range of between $11.64 \times 10^{0}$ to $9.54 \times 10^{0} \mathrm{cfu} / \mathrm{ml}$ while treatment $0.3 \%$ gave a range of between $9.69 \times 10^{0}$ to $8.27 \times 10^{\circ} \mathrm{cfu} / \mathrm{ml}$. This indicated a decrease in the yeast and moulds count during the five-week storage period. A significant difference was recorded on week two to week five with the control $(0.0 \%)$ having the highest level of counts from week one to week five. This could be attributed to lack of coffee extract in this treatment compared to the other treatments that showed antifungal effects of the coffee extract. Addition of coffee extract resulted to decreased growth of yeast and moulds in the yoghurt. It was also observed that yeast and moulds was sensitive to all the three concentrations of the coffee extract. This indicated that coffee extract had negative effect on the survival of yeast and moulds in yoghurt and it is in agreement with previous findings that caffeine and polyphenolic compounds have an antifungal activity on yeast and moulds [10]. The yeast and moulds pose danger to the safety and the keeping quality of the yoghurt.

Treatment $0.3 \%$ exhibited the lowest colony counts than the other treatments as shown in Table II. This could be attributed to the increased polyphenolic compounds present in coffee extracts due to increased concentration of the coffee extract, hence hindering multiplication of yeast and moulds. Reference [14] also indicated that polyphenolic compounds in coffee extract have ability to control growth of fungi. Concentration of yeast and moulds in yoghurt is a measure of food safety and should not be found above the stated limits of $\leq 100 \mathrm{cfu} / \mathrm{ml}$ according to Kenya Bureau of Standards specification [15]. In this research yeast and moulds ranged between 9 and $36 \mathrm{cfu} / \mathrm{ml}$ as shown in Table II. This was within the recommended limit. The yeast and moulds may contaminate the yoghurt from the surrounding air in the environment where yoghurt is produced. It is therefore recommended that, maintenance of good manufacturing practices in processing environments should be observed through regular cleaning disinfection, determination of the quality of the air coming into the packaging area or environment. In addition, management of ingredients that could introduce fungal contaminants into the process by use of antagonistic culture, preservatives and innovative packaging as strategies is important [16].

\section{Total Polyphenolic Compounds (TPC)}

The total phenolic compounds were evaluated, and the results shown in Table III. The total polyphenolic compounds in the different treatments were as follows; in $0.0 \%$ treatment total polyphenolic compounds ranged from $8.03^{\mathrm{a}} \pm 0.2 \mathrm{mgGAE} / \mathrm{ml}$ to $5.76^{\mathrm{d}} \pm 0.4 \mathrm{mgGAE} / \mathrm{ml}$, in $0.1 \%$ treatment, from $34.96^{\mathrm{b}} \pm 0.4$ to $32.96^{\mathrm{c}} \pm 0.8$, in $0.2 \%$ from $67.09^{\mathrm{c}} \pm 0.6$ to $63.23^{\mathrm{b}} \pm 0.61 \mathrm{mgGAE} / \mathrm{ml}$ and in $0.3 \%$ treatment it ranged from $97.89^{c} \pm 0.6$ to $95.89^{\mathrm{a}} \pm 0.23 \mathrm{mgGAE} / \mathrm{ml}$. There were significant differences among all treatments in week one with $0.3 \%$ having the highest value of TPC. This significant variation is attributed to the highest dosage of coffee extract used in the treatments. The treatments had different concentrations of phenolic compounds in the coffee extract as shown in Table III. It was evident that TPC was increasing with the increase in the coffee extract concentration. Significant differences were also observed in all treatments throughout the five weeks with treatment $0.3 \%$ having the highest values of TPC. Treatment $0.1 \%$ gave a TPC of $33.7 \mathrm{mgGAE} / \mathrm{ml}$ which was found to be significantly different from the other three treatments at $\mathrm{p} \leq 0.05$. Treatment $0.2 \%$ was found to have a mean of $67.94 \mathrm{mgGAE} / \mathrm{ml}$ which was also significantly different from the other three treatments at $\mathrm{p} \leq 0.05$. Treatment $0.3 \%$ which had the highest dose of the coffee extract gave $96.53 \mathrm{mgGAE} / \mathrm{ml}$ and was significantly higher than the means of other treatments. The results showed that the concentration of TPC increased with the increase in concentration of the coffee extract. This high value of TPC in treatment $0.3 \%$ was attributed to the higher concentration of coffee extract used in the samples. The level of TPC along the treatments showed a declining trend from week one to week five as shown in Table III. This gradual decline in the level of TPC in every treatment could be associated with LABs utilizing TPC for their metabolic activities and the linkages formed between TPC and proteins in the yoghurt [17]. The TPC was increasing as the coffee extract concentration increases. Treatment $0.0 \%$ did not contain any coffee extract and therefore its TPC was within the normal range found in fermented milk products [18]. Total phenolic compounds in milk could be contributed through naturally occurring phenolic compounds in the milk arising from the feeds animals consume [19]. The TPC levels are highly influenced by various compounds found in coffee including chlorogenic acid, cafeic acid, trigonneline, melanoidins and many other organic acids that contributes to the quality of coffee [10].

TABLE II: YEAST AND MOULDS IN COFFEE FLAVOURED YOGHURT

\begin{tabular}{cccccc}
\hline Treatments \% & \multicolumn{5}{c}{ Yeast and Moulds $\left(\times 10^{0}\right.$ cfu/ml $)$} \\
\cline { 2 - 6 } Coffee extract & Week 1 & Week 2 & Week 3 & Week 4 & Week 5 \\
\hline Control & $11.30 \pm 1.15^{\text {ab }}$ & $14.30 \pm 0.57^{\mathrm{a}}$ & $19.30 \pm 1.52^{\mathrm{a}}$ & $27.30 \pm 2.08^{\mathrm{a}}$ & $36.00 \pm 2^{\mathrm{a}}$ \\
0.1 & $9.87 \pm 0.57^{\mathrm{b}}$ & $8.93 \pm 0.57^{\mathrm{c}}$ & $8.67 \pm 0.57^{\mathrm{b}}$ & $8.67 \pm 0.57^{\mathrm{b}}$ & $8.33 \pm 0.57^{\mathrm{b}}$ \\
0.2 & $11.64 \pm 0.57^{\mathrm{a}}$ & $11.330 .57^{\mathrm{b}}$ & $9.61 \pm 2.08^{\mathrm{b}}$ & $9.61 \pm 1.52^{\mathrm{b}}$ & $9.54 \pm 2.08^{\mathrm{b}}$ \\
0.3 & $9.69 \pm 1.52^{\mathrm{b}}$ & $9.00 \pm 1^{\mathrm{c}}$ & $8.54 \pm 1.15^{\mathrm{b}}$ & $8.33 \pm 1.52^{\mathrm{b}}$ & $8.27 \pm 1.52^{\mathrm{b}}$ \\
\hline
\end{tabular}

The values are mean \pm standard deviation (SD) of three replicates. Values within a column marked with different superscript letters are significantly different (P<0.05). TABLE III: TOTAL PHENOLIC COMPOUNDS IN COFFEE FLAVOURED YOGHURT

\begin{tabular}{cccccc}
\hline Treatments & \multicolumn{4}{c}{ Total polyphenolic compounds (mgGAE/ml) } \\
\cline { 2 - 6 } \%coffee extract) & Week 1 & Week 2 & Week 3 & Week 4 & Week 5 \\
\hline Control & $8.03 \pm 0.2^{\mathrm{d}}$ & $7.76 \pm 0.4^{\mathrm{d}}$ & $7.23 \pm 0.46^{\mathrm{d}}$ & $6.56 \pm 0.4^{\mathrm{d}}$ & $5.76 \pm 0.4^{\mathrm{d}}$ \\
0.1 & $34.96 \pm 0.4^{\mathrm{c}}$ & $33.49 \pm 0.6^{\mathrm{c}}$ & $34.03 \pm 0.83^{\mathrm{c}}$ & $33.09 \pm 0.83^{\mathrm{c}}$ & $32.96 \pm 0.8^{\mathrm{c}}$ \\
0.2 & $67.09 \pm 0.6^{\mathrm{b}}$ & $66.29 \pm 1^{\mathrm{b}}$ & $65.1 \pm 0.68^{\mathrm{b}}$ & $64.03 \pm 0.61^{\mathrm{b}}$ & $63.23 \pm 0.61^{\mathrm{b}}$ \\
0.3 & $97.89 \pm 0.6^{\mathrm{a}}$ & $97.09 \pm 1^{\mathrm{a}}$ & $95.89 \pm 1^{\mathrm{a}}$ & $95.89 \pm 0.46^{\mathrm{a}}$ & $95.89 \pm 0.23^{\mathrm{a}}$ \\
\hline
\end{tabular}

The values are mean \pm standard deviation (SD) of three replicates. Values within a column marked with different superscript letters are significantly different $(\mathrm{P}<0.05)$ 
TABLE IV: ANTIOXIDANT ACTIVITY OF COFFEE FLAVOURED YOGHURT

\begin{tabular}{cccccc}
\hline \multirow{2}{*}{$\begin{array}{c}\text { Treatments } \\
\text { (\%coffee } \\
\text { extract) }\end{array}$} & Week 1 & Week 2 & Week 3 & Week 4 & Week 5 \\
\cline { 2 - 6 } & $19.15 \pm 0.5^{\mathrm{d}}$ & $19.46 \pm 0.9^{\mathrm{d}}$ & $18.24 \pm 0.5^{\mathrm{d}}$ & $15.82 \pm 0.9^{\mathrm{d}}$ & $16.73 \pm 0.9^{\mathrm{d}}$ \\
\hline Control & $41.58 \pm 1^{\mathrm{c}}$ & $42.79 \pm 1^{\mathrm{c}}$ & $39.46 \pm 0.9^{\mathrm{c}}$ & $37.33 \pm 0.5^{\mathrm{c}}$ & $34.30 \pm 1^{\mathrm{c}}$ \\
0.1 & $54.91 \pm 0.9^{\mathrm{b}}$ & $54 \pm 0.9^{\mathrm{b}}$ & $52.49 \pm 1^{\mathrm{b}}$ & $50.67 \pm 2.3^{\mathrm{b}}$ & $45.82 \pm 0.9^{\mathrm{b}}$ \\
0.2 & $68.55 \pm 0.9^{\mathrm{a}}$ & $66.73 \pm 0.9^{\mathrm{a}}$ & $64 \pm 0.9^{\mathrm{a}}$ & $62.49 \pm 1.4^{\mathrm{a}}$ & $57.94 \pm 1^{\mathrm{a}}$ \\
\hline
\end{tabular}

The values are mean \pm standard deviation (SD) of three replicates. Values within a column marked with different superscript letters are significantly different $(\mathrm{P}<0.05$ )

\section{Antioxidant Activity}

Functional properties in coffee flavoured yoghurt are influenced by the antioxidant activity of the coffee extract.

In this research antioxidant activity of the samples was as follows: in treatment $0.0 \%$ it ranged from $19.15 \pm 0.5$ to $16.73 \pm 0.9$, treatment $0.1 \%$ from $41.58 \pm 1$ to $34.30 \pm 1,0.2 \%$ from $54.91 \pm 0.9$ to $45.82 \pm 0.9$ and in treatment $0.3 \%$ antioxidant activity ranged from $68.55 \pm 0.9$ to $57.94 \pm 1$. There was an increase in antioxidant activity as the coffee extract concentration increases with significance difference recorded in all treatments for the five-week storage period. Treatment $0.3 \%$ recorded the highest value in all the five weeks as shown in Table IV. This could be attributed to the high concentration of coffee extract used in this treatments [12] as coffee is a rich source of phenolic compounds that are responsible for antioxidant activity of the coffee brew [10] There was a decline in antioxidant levels in all treatments during the storage period. The decline could be associated with the ability of lactic acid bacteria to utilize antioxidant compounds for their metabolic activities or due to the polyphenol protein interaction in the yoghurt [20]. Coffee extract is considered to contain phenolic compounds including; chlorogenic acid, caffeine, melanoidins that influence antioxidant activities [9]. Coffee extract, being rich in antioxidants have potential to benefit the consumer through incorporation in yoghurt. Treatment $0.0 \%$ showed the least antioxidant activity because it contained no added coffee extract. Its antioxidant activity could be attributed to the normal antioxidants found in milk contributed through naturally occurring phenolic compounds in the milk arising from the feeds animals consume [19]. This is in agreement with the reported finding that control yoghurt without pomegranate contained $17.91 \%$ DPPH activity [21]. The results also indicated that the higher the concentration of the coffee extract the higher the phenolic compounds hence the higher the antioxidant activity among the treatments [23]. Coffee flavoured yoghurt, a probiotic as well as prebiotic product has potential to boost human nutrition in addition to enhancing calcium bioavailability from the yoghurt.

\section{CONCLUSION}

In conclusion coffee extract does not affect the survival of lactic acid bacteria in the yoghurt but rather improves their survival thus making the coffee flavoured yoghurt a probiotic product. The lactic acid bacteria counts were maintained above $10^{6}$ in all treatments throughout the storage period, an indication that coffee extract improved the shelve life of the yoghurt. Growth and multiplication of yeasts and moulds during storage of yoghurt was negatively affected by addition of the coffee extract indicating potential for the coffee extract as an antifungal. Coffee extract was also found to influence the functional properties of the coffee flavoured yoghurt. It was evident that increased coffee extract concentration resulted to increase in the levels of antioxidant activity and the total polyphenolic compounds in the coffee flavoured yoghurt. Addition of coffee extract into yoghurt enriched the product with important functional properties that have potential health benefits to the consumer. A $2 \%$ rate of application of coffee extract into the yoghurt and regular consumption of the coffee flavoured yoghurt for functional benefits associated with health is recommended. The research further recommends more studies on addition of natural coffee flavour into other milk products.

\section{ACKNOWLEDGMENT}

I thank Dedan Kimathi University of Technology where I undertook the research, and Mr. Denis Kiptoo in charge of the yoghurt plant and Mr. Chuaga Kinuthia in charge of coffee research laboratory for their support during my experiments.

\section{REFERENCES}

[1] Weerathilake WAD V, Rasika DMD, Ruwanmali JKU, Munasinghe MADD. The evolution, processing, varieties and health benefits of yogurt. Int J Sci Res Publ [Internet]. 2014;4(1):2250-3153. Available from: www.ijsrp.org

[2] Baglio E. Springer briefs in molecular science. Chemistry and Technology of Yoghurt Fermentation. 2014. $62 \mathrm{p}$

[3] Ngeywo J. Gender based determinants of coffee consumption for management of coffee production in Kenya. 2016;(February).

[4] Nieber K. The impact of coffee on health author pharmacokinetics and mode of action bioactive components in coffee. Planta Med. 2017;83(1):1256-63.

[5] Pourshahidi LK, Navarini L, Petracco M, Strain JJ. A Comprehensive Overview of the Risks and Benefits of Coffee Consumption. Compr Rev Food Sci Food Saf. 2016;15(4):671-84.

[6] Król K, Gantner M, Tatarak A, Hallmann E. The content of polyphenols in coffee beans as roasting, origin and storage effect. Eur Food Res Technol [Internet]. 2020;246(1):33-9. Available from https://doi.org/10.1007/s00217-019-03388-9.

[7] Ramesh M, Muthuraman A. Risks and Potential Problems [Internet] Natural and Artificial Flavoring Agents and Food Dyes. Elsevier Inc.; 2018. 1-30 p. Available from: http://dx.doi.org/10.1016/B978-0-12811518-3/00001-6

[8] Khanum S, Safiullah M. Study of Harmful Effects of Consuming Food Additives and Public Awareness. 2018 Ijsrst | [Internet]. 2018;4(2):1071-4. Available from: www.ijsrst.com.

[9] Elhassaneen Y. Functional and Healthy Properties of Yoghurt adding to Green Tea and Coffee Extracts on Reducing Obese and its Complications in Rats:1-19. Available from: https://doi.org/10.21203/rs.3.rs-293107/v1.

[10] Mirón-Mérida VA, Yáñez-Fernández J, Montañez-Barragán B, Barragán Huerta BE. Valorization of coffee parchment waste (Coffea arabica) as a source of caffeine and phenolic compounds in antifungal gellan gum films. Lwt [Internet]. 2019;101:167-74. Available from: https://doi.org/10.1016/j.lwt.2018.11.013.

[11] AOAC G. Official methods of analysis of AOAC International. Rockville, MD: AOAC International, ISBN: 978-0-935584-87-5.

[12] Haile M, Kang WH. Antioxidant activity, total polyphenol, flavonoid and tannin contents of fermented green coffee beans with selected yeasts. Fermentation. 2019;5(1)

[13] Assefa, Daniel \& Workneh, M Determination of total phenolic content and antioxidant activities of five different brands of Ethiopian coffee. 
Int J Food Nutr Res [Internet]. 2017;1(2):2572-8784. Available from: https://pdfs.semanticscholar.org/967b/26b32dc2d91f5c9b2a863aebb1 e25e403f3c.pdf?_ga=2.79211668.168975831.15680249571633282329.1541604961.

[14] Bobková A, Hudáček M, Jakabová S, Belej L', Capcarová M, Čurlej J, et al. The effect of roasting on the total polyphenols and antioxidant activity of coffee. J Environ Sci Heal - Part B Pestic Food Contam Agric Wastes [Internet]. 2020;55(5):495-500. Available from: https://doi.org/10.1080/03601234.2020.1724660.

[15] Kim S. Optimization of Growth and Storage Conditions for Lactic Acid Bacteria in Yogurt and Frozen Yogurt. J Korean Soc Appl Biol Chem. 2009;52(1):76-9.

[16] M.H.Marhamatizadeh, Ehsandoost E, Gholami P. The Effect of Coffee Extract on the Growth and Viability of Lactobacillus Acidophillus and Bifidobacterium Bifidum in Probiotic Milk and Yoghurt. Food Biosci Technol., 2014;4(1):37-48.

[17] Castaldo L, Graziani G, Gaspari A, Izzo L, Luz C, Mañ J, et al. Study of the Chemical Components, Bioactivity and Antifungal Properties of the Coffee Husk. Journal of Food Research, 2018;7(4):43-54.

[18] Kenya Standard. Fermented (cultured) milks — Specification. 2018.

[19] Martin NH, Snyder A, Wiedmann M. Yeasts and Molds: Spoilage Mold in Dairy Products. Ref Modul Food Sci. 2020;(August):0-4.

[20] Dönmez Ö, Mogol BA, Gökmen V. Syneresis and rheological behaviors of set yogurt containing green tea and green coffee powders. $J$ Dairy Sci [Internet]. 2017;100(2):901-7. Available from: http://dx.doi.org/10.3168/jds.2016-11262.

[21] Cerbo A Di, Palmieri B, Aponte M, Morales-medina JC, Iannitti T. Mechanisms and therapeutic effectiveness of lactobacilli. Journal of clinical pathology, 2016;187-203.

[22] O'connell JE, Fox PF. Significance and applications of phenolic compounds in the production and quality of milk and dairy products: a review. International Dairy Journal, 2001 Jan 1;11(3):103-20.

[23] Farhana N, Ari AB, Ezuan M, Rios-solis L. In fl uence of probiotics, prebiotics, synbiotics and bioactive phytochemicals on the formulation of functional yogurt. Journal of Functional foods, 2018;48 (July):38799.

[24] El-said MM, Farahat AM. Antioxidant activities and physical properties of stirred yoghurt fortified with pomegranate peel extracts. 2014.available from https://doi.org/10.1016/j.aoas.2014.11.007.

[25] Olechno E, Puścion-Jakubik A, Markiewicz-Żukowska R, Socha K. Impact of Brewing Methods on Total Phenolic Content (TPC) in Various Types of Coffee. Molecules. 2020;25(22):1-17.

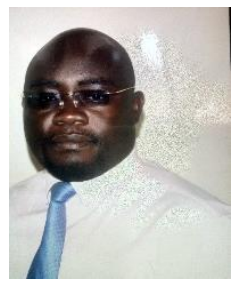

Jonah Mbae is M.Sc. Food Science and Technology student at Dedan Kimathi University of Technology, Kenya.

Undergraduated B.Sc. Food Science and Technology, Technical University of Kenya.

Area of specialization - Food microbiology, Food safety and Food chemistry. 